\title{
The role of social license in conservation
}

\author{
Dave Kendal $^{1,2, \dagger}, R^{2}$ ebecca M. Ford ${ }^{1}$
}

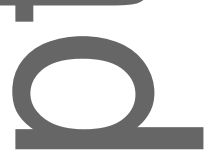

${ }^{1}$ School of Ecosystem and Forest Sciences, The University of Melbourne, Parkville, VIC, 3010, Australia

${ }^{2}$ Thrive Research Hub, Melbourne School of Design, Faculty of Architecture, Building and Planning, The University of Melbourne, Parkville, VIC, 3010, Australia

*Both authors contributed equally.

†emaildkendal@unimelb.edu.au

\section{Introduction}

“Threatened species programs need a social license to justify public funding" (Zander et al.

2014). Or do they? There is growing acceptance within conservation science that community support for and engagement in ecosystem management programs is likely to lead to better conservation outcomes (Marvier \& Wong 2012). However, the language used to characterize relations between conservation and the community is important, and use of the term social license may not always be a useful way to describe this relationship. Since the mid-1990s, the term social license has been widely used in the mining sector to describe implicit acceptance and approval of a mining operation by the community in which it operates (Lacey \& Lamont 2014). Other industries such as forestry, aquaculture, and agriculture have begun using the term in a similar way (Edwards \& Trafford 2016; Ford \& Williams 2016; Moffat et al.

This is the author manuscript accepted for publication and has undergone full peer review but has not been through the copyediting, typesetting, pagination and proofreading process, which may lead to differences between this version and the Version of Record. Please cite this article as doi: $\underline{10.1111 / \text { cobi.12994. }}$.

This article is protected by copyright. All rights reserved. 
2016). Now social license is beginning to appear in conservation discourse (e.g., Garnett et al., 2015; Oakes et al., 2015). At the same time, the use of social license in other sectors has been criticized (e.g., Owen \& Kemp, 2013) because it frames relationships with communities as more singular, binary, and tangible than is feasible or desirable (Parsons \& Moffat 2014). The use of social license in conservation needs critical evaluation, particularly given the broad contextual differences between conservation and industries such as mining.

The term sociat license has intersected with conservation in a number of ways. Conservation programs have been funded by mining and forestry companies to earn a social license to operate (Sonter et al. 2014). The term has also been used in similar ways to describe the need for conservation programs to earn support from the community. Conservation nongovernmental oganizations (NGOs) that seek broader community support for protectionist conservation activities that modify or exclude traditional land use in development contexts have been-described as needing a social license (Garnett et al. 2015). Now the term is migrating into the vocabulary of government-led conservation initiatives, where it is being used to describe the need for community support for conservation activities (e.g., Menz et al. 2013). For example, social license has been used as a proxy of support for management actions by visitors and managers of a national park (Oakes et al. 2015) and has been used interchangeably with social acceptability to understand local community response to the creation of a marine protected area (Voyer et al. 2014). The term is also being used in new ways that do not fit the license metaphor so easily. As quoted above, a social license has also been seen as a requirement for threatened species programs to justify public funding (Zander et al. 201

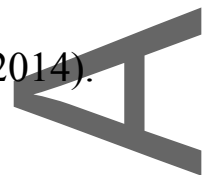

\section{The use of social license in industry}


The concept of a social license to operate was popularized in the mining industry in the mid1990s and was motivated by businesses seeking community acceptance of their activities (Lacey \& Lamont 2014). Calls for a social license can highlight the need for businesses to address social concerns, and the term is viewed by some as a useful rhetorical tool (Owen \& Kemp 2013) and a starting point for fostering dialogue between companies and stakeholders (Moffat et al. 2016). The idea of a social license can raise deeper questions about development and society, such as the alignment between management activities and society's values and expectations (Ford \& Williams 2016), the nature of the relationship between a company and its stakeholders (Moffat et al. 2016), and social justice in the outcomes of development (Lacey \& Lamont 2014). However, critics argue that social license can create the appearance of business accommodating community concerns to claim reputational capital while understanding and addressing the real complexity and dynamics of community concerns is avoided (Owen \& Kemp 2013; Moffat et al. 2016).

Part of the appeal of the license metaphor is that it invites parallels with the process by which a company is granted a formal license by government to undertake operations (Moffat et al. 2016). Onthe surface, a social license alludes to an agreement that is similarly tangible, singular, and enduring (Ford \& Williams 2016). However, acceptance of operations by a community is usually implied rather than expressed directly through any formal process, is difficult to define, and is open to multiple interpretations (Parsons \& Moffat 2014). Relations r. between society and land managers are much more complex and dynamic than the license metaphor suggests (Dare et al. 2014; Ford \& Williams 2016). Most communities are heterogeneous (Ojha et al. 2016), particularly in relation to environmental issues (Kendal et al. 2015; Ford \& Williams 2016). The community may include local people with very different interests, as well as national and international stakeholders (Moffat et al. 2016). In practice this means it is not always clear who could legitimately grant a social license, and 
multiple social licenses could need to be negotiated (Dare et al. 2014). Societies and communities change over time (Ojha et al. 2016), which means a social license could need to these reasons, the license metaphor has been criticized as a poor fit with the kinds of relationships that land managers need to maintain to achieve support and acceptance of programs (Ford \& Williams, 2016). This ambiguity can leave social license open to application for political purposes by different groups in society (Moffat et al. 2016).

\section{Conservation's need for a social license}

The term social license is beginning to be used in the context of conservation programs run by governments and their agencies and partners (e.g. Voyer et al. 2014; Oakes et al. 2015).

Because government has a different relationship with society than private companies, the role of a social license in this context is necessarily different (e.g. Moffat et al. 2016). For ren example, members of the public expect governments to act in the public interest, and increasingly the public sector is partnering with communities to help them articulate interests and values and direct resources accordingly (Denhardt \& Denhardt 2000). In conservation governance is becoming ever more complex; volunteer groups, businesses, and NGOs are taking on roles that were previously carried out by government (Lane \& Morrison 2006). These models are not necessarily founded in the same kinds of legitimacy as traditional government initiatives because government, communities, and NGOs work in complex networks to achieve management outcomes (Ojha et al. 2016). Community members may be active participants in conservation actions (e.g., Reid et al. 2011) rather than passive observers who have an instrumental and distant role as approvers. The metaphor of a license is less appealing in these contexts than it is in a business one. 
Yet some biodiversity conservation initiatives do invite parallels with the way social license has been used in mining and forestry. First, conservation programs are increasingly leading to conflict with communities, particularly where they involve land-use change (Redpath et al. 2013; Colvin et al. 2015). For example, protected areas created through structured technical processes (e.g. Voyer et al. 2014), may be based in a narrow set of scientific values and may not be wellaligned with the broader values of local communities and existing land users. Second, the new hybrid models of governance have brought business concepts and marketbased instruments to conservation (Lockwood \& Davidson 2010) that can undermine the networks of trust that decentralized community-based approaches are founded on (e.g., Curtis et al. 2014). In these situations, the support of the local communities may need to be earned in ways that parallel the need for a social license for mining and forestry operations.

\section{Conclusion}

In developing effective networks and relationships between communities and institutions, language is important. The social-license metaphor has been criticized in forestry and mining for overly simplifying the relationship between operations and local communities. In conservation, where communities are important and often active partners in complex governance arrangements, the term seems even less appealing. Promoting the need for a social license draws attention to the importance of public and community perspectives in conservation, but care must be taken to avoid undermining public and community support by adopting a language that is associated with a lack of desire for genuine relationships among the very communities that conservation wants to have on its side.

Language is dynamic and it is possible that social license will escape its metaphorical roots. Emerging academic research on social license usefully highlights important factors that support effective relationships with communities framed as a social license, such as trust and 
fair process (Moffat \& Zhang 2014) and ethical alignment between business and civil society (Lacey and Lamont 2014). Other concepts such as social acceptance (Stankey \& Shindler 2006) and social values (Ives \& Kendal 2014) explicitly recognize complexity and diversity in communities and could be used when engaging with communities and seeking support for conservation programs. Whatever terminology is used, it is important that conservation practitioners develop trusting, ongoing relationships with active participants, local residents, and the broader public that understand and recognize the diversity, dynamism, and complexity of views held by the community.

\section{Acknowledgments}

D.K. is supported by the Clean Air and Urban Landscape hub of the National Environmental Science Program.We thank the anonymous reviewers who helped to greatly improve this manuscript.

\section{Literature Cited}

Colvin RM, Witt GB, Lacey J. 2015. The social identity approach to understanding sociopolitieal conflict in environmental and natural resources management. Global Environmental Change 34:237-246.

Curtis A, Ross H, Marshall GR, Baldwin C, Cavaye J, Freeman C, Carr A, Syme GJ. 2014. The great experiment with devolved NRM governance: lessons from community engagement in Australia and New Zealand since the 1980s. Australasian Journal of Environmental Management 21:175-199.

Dare ML, Schirmer J, Vanclay F. 2014. Community engagement and social licence to operate. Impact Assessment and Project Appraisal 32:188-197.

Denhardt R, Denhardt J. 2000. The new public service: Serving rather than steering. Public This article is protected by copyright. All rights reserved. 
Administration Review:549-559.

Edwards P, Trafford S. 2016. Social licence in New Zealand-what is it? Journal of the Royal Society of New Zealand 46:165-180.

Ford RM, Williams KJH. 2016. How can social acceptability research in Australian forests inform social licence to operate? Forestry 89:512-524.

Garnett ST, Lawes MJ, James R, Bigland K, Zander KK. 2015. Portrayal of sustainability principles in the mission statements and on home pages of the world's largest organizations. Conservation Biology 30:297-307.

Ives CD, Kendal D. 2014. The role of social values in the management of ecological systems. Journal of Environmental Management 144:67-72.

Jepson P. 2005. Governance and accountability of environmental NGOs. Environmental Science and Policy 8:515-524.

Kendal D, Ford RM, Anderson NM, Farrar A. 2015. The VALS: a new tool to measure people's general valued attributes of landscapes. Journal of Environmental Management 163:224-233

Lacey J, Lamont J. 2014. Using social contract to inform social licence to operate: an application in the Australian coal seam gas industry. Journal of Cleaner Production $84: 831-8 \cdot 2$

\section{4:83}

Lane MB, Morrison TH. 2006. Public interest or private agenda? Journal of Rural Studies $22: 232-242$.

Lockwood M, Davidson J. 2010. Environmental governance and the hybrid regime of Australian natural resource management. Geoforum 41:388-398. 
Marvier M, Wong H. 2012. Resurrecting the conservation movement. Journal of Environmental Studies and Sciences 2:291-295.

Menz MHM, Dixon KW, Hobbs RJ. 2013. Hurdles and opportunities for landscape-scale restoration. Science 339:526-527.

Moffat K, Lacey J, Zhang A, Leipold S. 2016. The social licence to operate: a critical review. Forestry 89:477-488.

Moffat K, Zhang A. 2014. The paths to social licence to operate: An integrative model explaining community acceptance of mining. Resources Policy 39:61-70.

Oakes LE, Hennon PE, Ardoin NM, D’Amore D V., Ferguson AJ, Ashley Steel E, Wittwer DT, LambinEF. 2015. Conservation in a social-ecological system experiencing climateinduced tree mortality. Biological Conservation 192:276-285.

Ojha HR, Ford R, Keenan RJ, Race D, Carias Vega D, Baral H, Sapkota P. 2016.

Deloealizing Communities: Changing Forms of Community Engagement in Natural Resources Governance. World Development 87:274-290.

Owen JR, Kemp D. 2013. Social licence and mining: a critical perspective. Resources Policy 38:29-35.

Parsons R, Moffat K. 2014. Constructing the meaning of social licence. Social Epistemology 28:34

Redpath SM et al. 2013. Understanding and managing conservation conflicts. Trends in Ecology \& Evolution 28:100-109.

Reid KA, Williams KJH, Paine MS. 2011. Hybrid knowledge : place , practice , and knowing in a volunteer ecological restoration project. Ecology and Society 16 DOI: 10.5751/ES- 
04234-160319.

Sonter LJ, Barrett DJ, Soares-Filho BS. 2014. Offsetting the impacts of mining to achieve no net loss of native vegetation. Conservation Biology 28:1068-1076.

StankeyGH, Shindler B. 2006. Formation of social acceptability judgments and their ( implications for management of rare and little-known species. Conservation Biology 20:28-37.

Voyer M, Gladstone W, Goodall H. 2014. Obtaining a social licence for MPAs - influences on social acceptability. Marine Policy 51:260-266.

Zander KK, Ainsworth GB, Meyerhoff J, Garnett ST. 2014. Threatened bird valuation in Australia. PLoS ONE 9 (e100411) DOI:10.1371/journal.pone. 0100411.
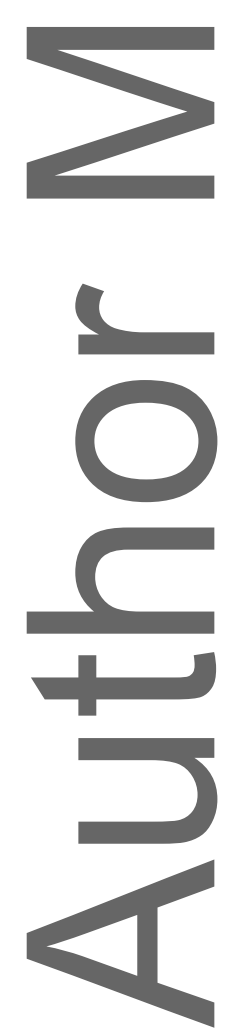


\section{University Library}

\section{- M M N E R VA A gateway to Melbourne's research publications}

Minerva Access is the Institutional Repository of The University of Melbourne

Author/s:

Kendal, D;Ford, RM

Title:

The role of social license in conservation

Date:

2018-04-01

Citation:

Kendal, D. \& Ford, R. M. (2018). The role of social license in conservation. CONSERVATION BIOLOGY, 32 (2), pp.493-495. https://doi.org/10.1111/cobi.12994.

Persistent Link:

http://hdl.handle.net/11343/293382 